- Sérgio Luiz Ramin

- Waldir Antonio Tognola

- Antonio Ronaldo Spotti

\title{
Proton magnetic resonance spectroscopy: clinical applications in patients with brain lesions
}

\author{
Department of Neurological Sciences, Faculdade de Medicina de São José \\ do Rio Preto, São José do Rio Preto, São Paulo, Brazil
}

\section{ABSTRACT}

CONTEXT: Proton spectroscopy has been recognized as a safe and noninvasive diagnostic method that, coupled with magnetic resonance imaging techniques, allows for the correlation of anator niques, allows for the correlation of anatomical and physiological changes in the metabolic and biochemical processes occurring within previouslydetermined volumes in the brain. There are two methods of proton magnetic resonance spectroscopy: single voxel and chemical shift imaging

OBJECTIVE: The present work focused on the clinical applications of proton magnetic resonance spectroscopy in patients with brain lesions.

CONCLUSIONS: In vivo proton spectroscopy allows the detection of certain metabolites in brain tissue, such as $\mathrm{N}$-acetyl aspartate, creatine, choline, myoinositol, amino acids and lipids, among others. $\mathrm{N}$-acetyl aspartate is a neuronal marker and as such, its concentration will decrease in the presence of aggression to the brain. Choline increase is the main indicator of neoplastic diseases. Myoinositol is raised in patients with Alzheimer's disease. Amino acids are encountered in brain abscesses. The presence of lipids is related to necrotic processes.

KEY WORDS: Proton. Spectroscopy. Magnetic resonance. Brain

\section{....... INTRODUCTION}

The basic principles of magnetic resonance have been known since the 1940s, but due to technical difficulties the first imaging of the human body via magnetic resonance was only achieved at the beginning of the 1980s. In contrast, between the development of the principles of $x$-rays and the first images produced by that method there was a time interval of only four months. ${ }^{1}$

Magnetic resonance imaging is an excellent method for anatomical and structural diagnosis of the brain, but it does not provide functional or metabolic information. At the beginning of the 1990s, one of the options for assessing the metabolic and functional activity of the brain was positron emission tomography or functional magnetic resonance (diffusion, perfusion and spectroscopy), ${ }^{2,3}$ which was used mainly in research institutes. The equipment necessary for this purpose was expensive and inaccessible for most medical centers of the world and still is, in the case of positron emission tomography.

In the mid-1990s, however, the development of computer software for spectroscopy coupled to the previously existing magnetic resonance equipment contributed towards reducing prices. For this reason, the clinical use of spectroscopy using in vivo magnetic resonance has become routine in many hospitals. ${ }^{4}$

\section{Magnetic resonance spectroscopy}

Magnetic resonance spectroscopy is used to detect the metabolic and biochemical profile of brain areas. ${ }^{4}$ Several chemical elements can be used to obtain magnetic resonance spectroscopy such as phosphorus, ${ }^{5-7}$ carbon $^{8,9}$ and hydrogen. ${ }^{10}$

The first in vivo magnetic resonance spectroscopy was performed at the beginning of the 1980s and was done using resonance of the phosphorus nucleus $\left({ }^{31} \mathrm{P}\right)$, thereby revealing the energy metabolism of the tissue cells studied. ${ }^{7}$ However, this method had the disadvantages of low magnetic sensitivity, low concentration of ${ }^{31} \mathrm{P}$ atoms and also inadequate spatial resolution in focal brain lesions with small and mild dimensions, ${ }^{7}$ and it has been replaced by proton (hydrogen) spectroscopy, especially in brain studies. ${ }^{10}$

Proton $\left({ }^{1} \mathrm{H}\right)$ resonance is nowadays the method most frequently used in neurospectroscopy, because hydrogen is the most abundant atom in the human body and its nucleus emits the most intense radiofrequency signal, when in an external magnetic field, in relation to other nuclei. ${ }^{10}$ Moreover, proton magnetic resonance spectroscopy is more quickly accomplished and easily interpreted.

\section{In vivo proton magnetic resonance spectroscopy}

In 1989, Frahm et al. ${ }^{11,12}$ published the first reports of in vivo proton magnetic resonance spectroscopy, describing the methodology used in the detection and measurement of metabolite concentrations in the human brain.

Proton spectroscopy has been recognized as a noninvasive method, approved since 1996 by the Food and Drug Administration (FDA). Coupled with magnetic resonance imaging techniques, it allows for the corre- 
lation of anatomical and physiological changes in the metabolic and biochemical processes occurring within previously-determined volumes in the brain. ${ }^{13}$

Proton magnetic resonance spectroscopy of the brain is useful whenever biochemical or metabolic assessment may be necessary, such as in differential diagnosis of focal brain lesions (neoplastic and non-neoplastic diseases); ${ }^{14-20}$ brain lesions in patients with acquired immunodeficiency syndrome; ${ }^{21-23} \mathrm{di}-$ agnosis of dementia ${ }^{24-26}$ and other degenerative diseases $;{ }^{27}$ follow-up radiation therapy for patients with brain neoplasms; ${ }^{28-30}$ demyelinating diseases such as multiple sclerosis ${ }^{31-33}$ and leukodystrophy; ${ }^{6,34}$ diagnosis and prognosis of brain ischemic ${ }^{35,36}$ and traumatic lesions; ;7-42 assessment of epilepsy; ${ }^{43-45}$ biochemical alterations in hepatic encephalopathies; ${ }^{46,47}$ and neuropediatric affections such as brain tumors, inborn errors of metabolism and hypoxic encephalopathy. ${ }^{48-50}$

Magnetic resonance examinations, including spectroscopy, are absolutely contraindicated in patients with heart pacemakers or other electronic appliances implanted in the body, and those with steel clips in brain aneurysms. Individuals with claustrophobia and children need sedation. ${ }^{51}$

\section{Techniques}

There are two methods of proton magnetic resonance spectroscopy: single voxel and multivoxel, with or without spectroscopic imaging. Single voxel proton magnetic resonance spectroscopy provides a rapid biochemical profile of a localized volume within a region of interest that may be determined, especially in brain studies. ${ }^{4,16,52,53}$ Spectroscopic imaging provides biochemical information about multiple, small and contiguous volumes focalized on a particular region of interest that may allow the mapping of metabolic tissue distribution. By using this method, the data obtained may be manipulated by computer and superimposed on the image of an abnormality, thereby illustrating the distribution of such metabolites within that area. ${ }^{54-56}$

The two localization methods commonly used in clinical proton magnetic resonance spectroscopy are PRESS (point-resolved spectroscopy) and STEAM (stimulated echo acquisition mode). Both methods stimulate protons within the volume of interest with minimal stimulation outside of this volume. ${ }^{11,13,36,52,57-61}$

Another essential variable in the acquisition of proton magnetic resonance spectroscopy is the choice of echo time. With short echo times (less than 30 milliseconds), the magnetic resonance spectrum detects larger numbers of metabolites, but it is more likely that peak superimposition will occur, thereby causing difficulty in spectroscopic curve interpretation. Short echo times are indicated for the study of metabolic and diffuse diseases. ${ }^{52}$ By using long echo times (more than 135 milliseconds), smaller numbers of metabolites are detected, but with better definition of peaks, thereby facilitating graphic analysis. Long echo times are more used in focal brain lesions. ${ }^{62}$

\section{Metabolites: localization and importance}

In vivo proton magnetic resonance spectroscopy allows the presence of certain metabolites in brain tissue to be detected if the minimum concentrations are between 0.5 and $1.0 \mathrm{mM}^{6}$ Some of these present clinical importance, ${ }^{25,48,49,63-72}$ such as:

1. N-acetyl aspartate (Naa) - this is a neuronal marker that is present in neuron bodies and axons, and indicates their density and viability. Its production takes place in the mitochondria of brain tissue. Because of these factors, the Naa peak in proton spectroscopy will be decreased whenever there is neuron loss, such as in glioma, ischemia and degenerative diseases. Naa presence resonates at 2.02 parts per million (ppm)

2. Creatine $(\mathrm{Cr})-$ this is a marker of the aerobic energy metabolism of the brain cells, and is present in larger concentrations in the gray matter than in the white. The creatine peak is practically constant and may be used as a control value in relation to other metabolites. Creatine phosphate also contributes to the $\mathrm{Cr}$ peak. Occasionally, a reduction in the $\mathrm{Cr}$ peak occurs in brain tumors, mainly in metastases. The peak for $\mathrm{Cr}$ is seen at 3.02 ppm; however, an additional peak for creatine may be visible at $3.94 \mathrm{ppm}$

3. Choline (Cho) - this is a constituent molecule of the phospholipid metabolism of cell membranes and reflects membrane turnover. Its concentration is slightly greater in white matter than in gray matter. Increased choline indicates greater membrane synthesis and cell proliferation. Its concentration is normally greatly increased in cases of brain neoplastic expansible processes. Phosphocholine and glycerophosphocholine also contribute to the representation of the Cho peak, which occurs at $3.2 \mathrm{ppm}$

4. Lactate - this is not commonly detected in proton spectroscopy of brain tissue. Its presence indicates a pathological condition with regard to the final products of anaerobic metabolism. Lactate can be identified in cysts, hypoxic/ischemic tissues and some neoplasms. It is visible as an inverted double peak on the spectroscopic curve (echo time of $136 \mathrm{~ms}$ ) at $1.33 \mathrm{ppm}$

5. Lipids - these metabolites are usually not detected by proton magnetic resonance spectroscopy, either. In pathological situations in which necrosis occurs, such as in malignant neoplasms and inflammatory/infectious processes, there is an accentuated lipid peak, signifying cell membrane degradation. This peak is located at 0.9 and $1.3 \mathrm{ppm}$

6. Myoinositol - this is considered to be a glial function marker, and it is an important osmotic agent regulator for cell volume. It generally presents reduction in hepatic encephalopathy and elevation in Alzheimer's disease. The myoinositol peak occurs at $3.56 \mathrm{ppm}$.

In pathological cases, other metabolites that can be detected via proton magnetic resonance spectroscopy include the following amino acids: a) alanine, as an inverted double peak in meningiomas and brain abscesses (at $1.48 \mathrm{ppm}$ with an echo time of $136 \mathrm{~ms}$ ); b) acetates and succinates in abscesses and neurocysticercosis (at 1.92 and $2.4 \mathrm{ppm}$, respectively); and c) cytosols in abscesses (at $0.9 \mathrm{ppm})$.

\section{Interpretation of the spectroscopic curve}

The spectrum represents radiofrequency signals emitted from the proton nuclei of the different metabolites into the region of interest. Specific metabolites always appear at the same frequencies, expressed as parts per million, and are represented on the horizontal axis of the graph. The vertical axis shows the heights of the metabolite peaks, represented on an arbitrary intensity scale. Figure 1 shows proton spectroscopic curves for the magnetic resonance of normal brain tissue, with the $\mathrm{N}$ acetyl aspartate, creatine and choline peaks.

The study of proton magnetic resonance spectroscopy can be either qualitative or quantitative. Qualitative study results in graphs of metabolites from a given region of the brain. Quantitative study measures the real concentration of metabolites, which is proportional to the area under the peak, or the relationship of their rates with each other, through height measurement of the peaks on the graph. 


\section{Main clinical applications}

\section{Brain tumors}

Proton magnetic resonance spectroscopy is a very sensitive method for detecting brain tumors. Decreased intensity of the N-acetyl aspartate peak and increased choline occur in gliomas (Figure 2). ${ }^{25}$ Lactate peaks may be found in such tumors, independent of their malignancy grade, ${ }^{33,53}$ thereby indicating hypoxia. There is controversy regarding the capacity of proton spectroscopy to distinguish between different histological grades of gliomas; however, the detection of lipids is typical of multiform glioblastoma, i.e. tissue necrosis. ${ }^{14}$ When the image obtained by magnetic resonance does not succeed in differentiating glioma from infection, the proton magnetic resonance spectroscopy is useful, because in neoplastic processes there is a remarkable increase in the choline peak. ${ }^{73,74}$ Moreover, this method is important in monitoring responses to the treatment of gliomas. ${ }^{75}$

Although the diagnosis of meningioma is easily done by means of magnetic resonance imaging, proton magnetic resonance spectroscopy may be useful in atypical cases.
In such tumors there is a pronounced rise in choline levels, associated with absence or considerable reduction of $\mathrm{N}$-acetyl aspartate. ${ }^{4}$ Presence of an alanine peak can confirm the diagnosis (Figure 3). ${ }^{65}$

\section{Inflammatory and infectious processes}

The main application of proton magnetic resonance spectroscopy in inflammatory and infectious processes is the establishment of differential diagnoses between these processes and brain tumors.

In focal inflammatory processes in patients with acquired immunodeficiency syndrome (aids), such as toxoplasmosis (Figure 4), tuberculosis or cryptococcosis, proton spectroscopy shows a broad lipid peak and occasionally a lactate peak, with a decrease or absence of $\mathrm{N}$-acetyl aspartate and slight increase of choline (Figure 4). ${ }^{20,22}$

In pyogenic abscesses, $\mathrm{N}$-acetyl aspartate, creatine and choline peaks are not detected and the spectroscopic curve presents amino acid peaks, especially succinate, acetate and cytosolic peaks, due to the great quantity of hydrolytic enzymes produced by bacteria, which results in elevated concentrations of proteins and amino acids..$^{20,41,63}$

\section{Alzheimer's disease}

Proton magnetic resonance spectroscopy shows a reduction of $\mathrm{N}$-acetyl aspartate in the frontoparietal, temporal and hippocampus regions, due to the neuron loss and increase in myoinositol concentration. ${ }^{25,26}$ These results can be found even in light and mild cases of dementia, thus reinforcing the importance of this method for early diagnosis of Alzheimer's disease. ${ }^{24}$ However, there is still controversy regarding the sensitivity of proton magnetic resonance spectroscopy in such cases.

\section{Ischemic lesions}

The main characteristic of the spectroscopic curve in acute brain ischemia is the early appearance of a lactate peak, decrease of $\mathrm{N}$ acetyl aspartate and slight increase of choline (Figure 5). ${ }^{33}$ It detects lactate within the first minutes of ischemia and, at the subacute phase, its concentration is progressively reduced. The intensity of these peaks in the infarcted area is related to the prognosis. ${ }^{34}$

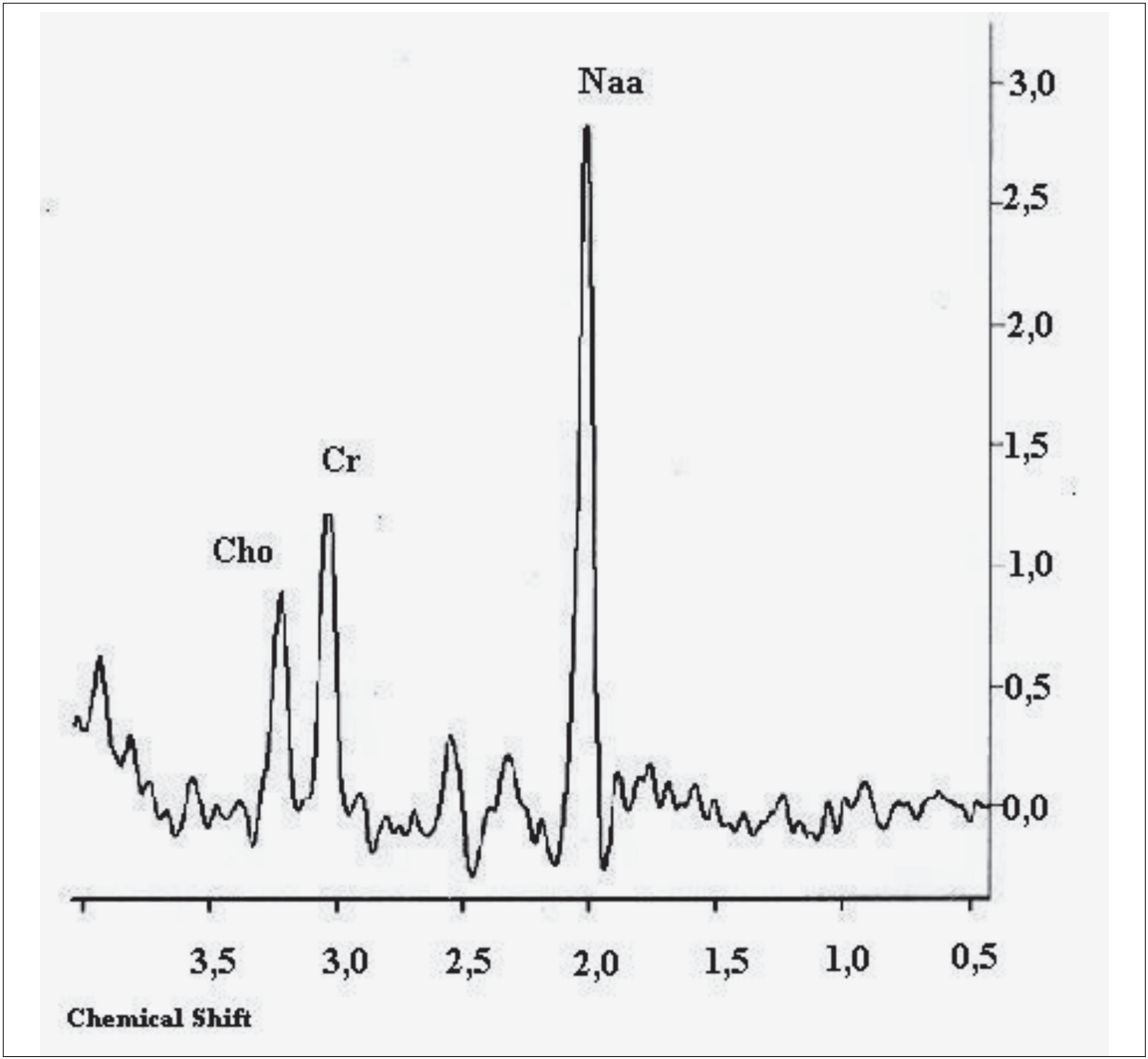

Figure 1. Normal brain curve from proton magnetic resonance spectroscopy of the brain, showing peaks of the metabolites $N$ acetyl aspartate (Naa), creatine $(\mathrm{Cr})$ and choline (Cho), with echo time of 136 milliseconds.

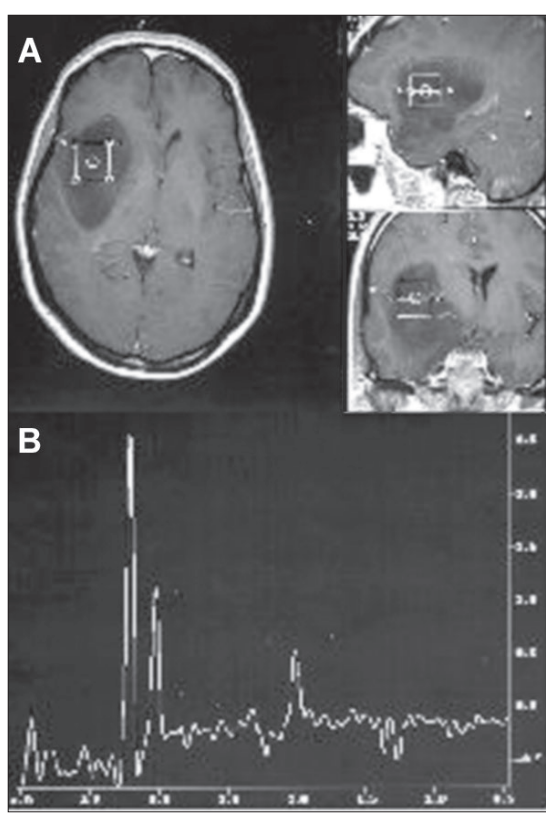

Figure 2. A-Magnetic resonance imaging in the axial, sagittal and coronal planes of the brain ( $T_{1}$-weighted), showing hypointense frontoparietal lesion without postgadolinium enhancement, in voxel position, typical of low-grade astrocytoma. B-Spectroscopic curve from proton magnetic resonance with echo time of 136 milliseconds. Note inverted double peak of lactate $(1.33 \mathrm{ppm})$, decrease in the $\mathrm{N}$-acetyl aspartate peak (2.02 ppm) and pronounced increase in the choline peak (3.2 ppm). 


\section{Hepatic encephalopathy}

The diagnosis of hepatic encephalopathy in most cases is difficult and, moreover, many patients have a subclinical form of the dis-

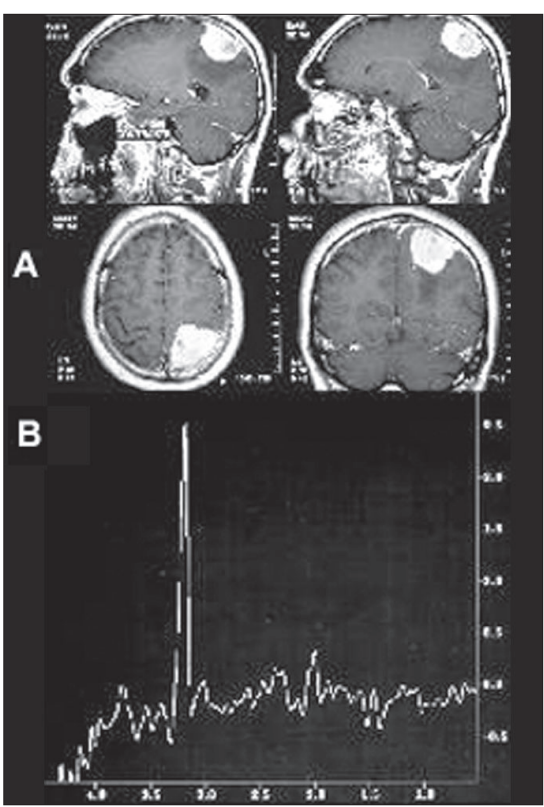

Figure 3. A-Magnetic resonance imaging of the brain in the axial, sagittal and coronal planes ( $T_{1}$-weighted), showing parietal lesion with homogeneous postgadolinium enhancement, typical of meningioma. B-Spectroscopic curve from proton magnetic resonance with echo time of 136 milliseconds, demonstrating inverted double peak of alanine (1.48 ppm), accentuated decrease in the $N$-acetyl aspartate peak $(2.02 \mathrm{ppm})$ and pronounced increase in the choline peak (3.2 ppm). ease. Proton magnetic resonance spectroscopy shows an elevation of glutamate and glutamine levels (peak between 2.1 and 2.5 ppm) and a reduction in choline and myoi-
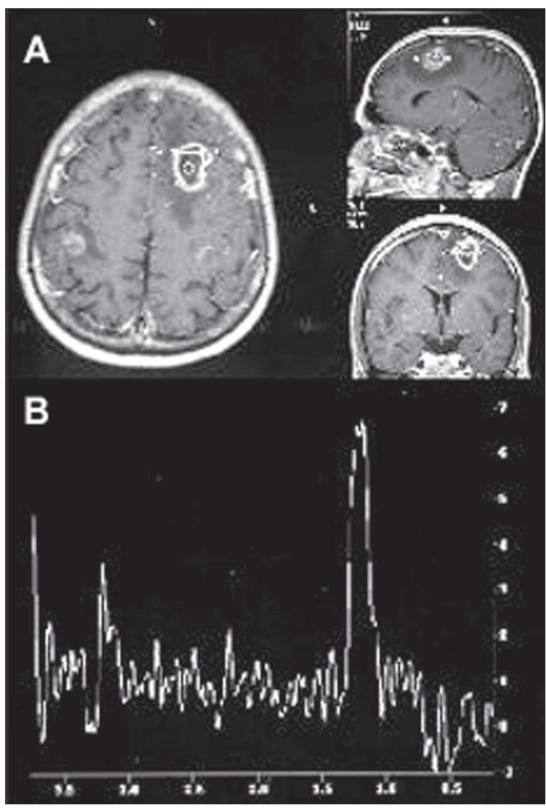

Figure 4. A-Magnetic resonance imaging of the brain in the axial, sagittal and coronal planes ( $T_{I}$-weighted), showing frontoparietal ring-like postgadolinium lesion enhancement and voxel position, in patient with toxoplasmosis. B- Spectroscopic curve from proton magnetic resonance with echo time of 136 milliseconds, demonstrating accentuated lipid peak (1.3 ppm), absence of $N$-acetyl aspartate peak (2.02 ppm) and slight increase in the choline peak (3.2 ppm). nositol levels. ${ }^{45,46}$ These metabolic alterations can be detected before the appearance of lesions through imaging examinations using magnetic resonance. ${ }^{63}$

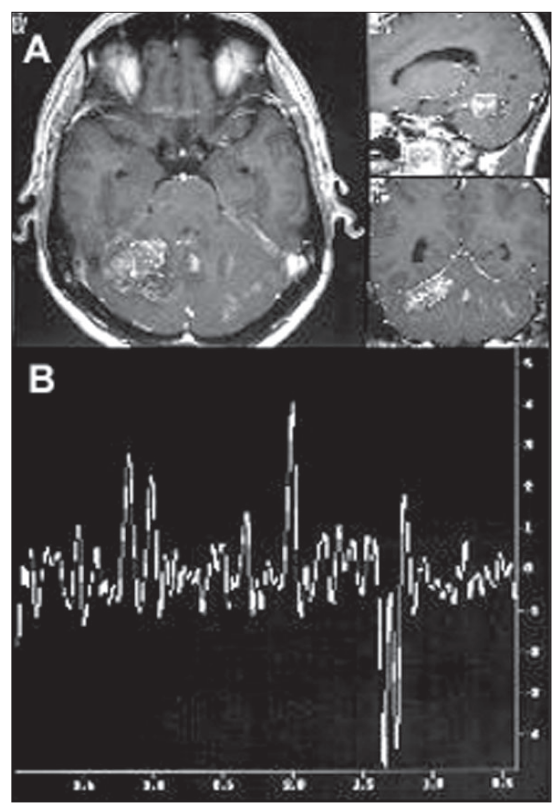

Figure 5. A-Magnetic resonance imaging of the brain in the axial, sagittal and coronal planes ( $T_{1}$-weighted), showing lesion in the right cerebellar hemisphere with heterogeneous postgadolinium enhancement and voxel position, in patient with acute ischemia. B-Spectroscopic curve from proton magnetic resonance with echo time of 136 milliseconds, demonstrating inverted double peak of lactate (1.33 ppm), decrease in $N$-acetyl aspartate peak (2.02 ppm) and slight increase in the choline peak (3.2 ppm). 
1. Lenkinski RE, Schnall MD. MR Spectroscopy and the biochemical basis of neurological disease. In: Atlas SW, editor. Magnetic resonance imaging of the brain and spine. Philadelphia: Lippincott-Raven; 1996. p.1619-53.

2. Alger JR, Frank JA, Bizzi A, et al. Metabolism of human gliomas: assessment with $\mathrm{H}-1$ MR spectroscopy and F-18 fluorodeoxyglucose PET. Radiology 1990;177(3):633-41.

3. Luyten PR, Marien AJ, Heindel W, et al. Metabolic imaging of patients with intracranial tumors: H-1 MR spectroscopic imaging and PET. Radiology 1990;176(3):791-9.

4. Norfray J, Byrd SE, Schwalm CA. Magnetic resonance spectroscopy. In: McLone DG, ed. Pediatric neurosurgery. Philadelphia: WB Saunders; 2001. p.1189-203.

5. Kuzniecky R. Magnetic resonance spectroscopy in focal epilepsy: 31P and 1H spectroscopy. Rev Neurol 1999;155(67):495-8.

6. Ross B, Michaelis T. MR spectroscopy of the brain: neurospectroscopy. In: Hesselink JR, Zlatkin MB, Edelman RR, editors. Clinical magnetic resonance imaging. Philadelphia: WB Saunders; 1996. p.928-81.

7. van der Knaap MS, van der Grond J, van Rijen PC, Faber JA, Valk J, Willemse K. Age-dependent changes in localized proton and phosphorus MR spectroscopy of the brain. Radiology 1990;176(2):509-15.

8. Peeling J, Sutherland G, Marat K, Tomchuk E, Bock E. 1H and 13C nuclear magnetic resonance studies of plasma from patients with primary intracranial neoplasms. J Neurosurg 1988;68(6):931-7.

9. Gruetter R. Localized ${ }^{13} \mathrm{C}$ NMR spectroscopy in vivo. In: Weekend Educational Courses: MR spectroscopy. Honolulu: International Society for Magnetic Resonance in Medicine; 2002. p.88-95.

10. Weiner MW, Hetherington HP. The power of the proton. Radiology 1989;172(2):318-20.

11. Frahm J, Bruhn H, Gyngell ML, et al. Localized high-resolution proton NMR spectroscopy using stimulated echoes: initial applications to human brain in vivo. Magn Reson Med 1989;9(1):79-83.

12. Frahm J, Bruhn H, Gyngell ML, et al. Localized proton NMR spectroscopy in different regions of the human brain in vivo. Relaxation times and concentrations of cerebral metabolites. Magn Reson Med 1989;11(1):47-63.

13. Kwock L. Localized MR spectroscopy: basic principles. Neuroimaging Clin N Am 1998;8(4):713-31.

14. Butzen J, Prost R, Chetty V, Donahue K, Neppl R, Bowen W, et al. Discrimination between neoplastic and nonneoplastic brain lesions by use of proton MR spectroscopy: the limits of accuracy with a logistic regression model. AJNR Am J Neuroradiol 2000;21(7):1213-9.

15. Wilken B, Dechent P, Herms J, et al. Quantitative proton magnetic resonance spectroscopy of focal brain lesions. Pediatr Neurol 2000;23(1):22-31.

16. Adamson AJ, Rand SD, Prost RW, et al. Focal brain lesions: effect of single-voxel proton MR spectroscopic findings on treatment decisions. Radiology 1998;209(1):73-8.

17. Simone IL, Federico F, Tortorella C, et al. Localised 1H-MR spectroscopy for metabolic characterisation of diffuse and focal brain lesions in patients infected with HIV. J Neurol Neurosurg Psychiatry 1998;64(4):516-23

18. Poptani H, Kaartinen J, Gupta RK, et al. Diagnostic assessment of brain tumours and non-neoplastic brain disorders in vivo using proton nuclear magnetic resonance spectroscopy and artificial neural networks. J Cancer Res Clin Oncol 1999; 125(6):343-9

19. Kaibara T, Tyson RL, Sutherland GR. Human cerebral neoplasms studied using MR spectroscopy: a review. Biochem Cell Biol 1998;76(2-3):477-86.

20. Cecil KM, Lenkinski RE. Proton MR spectroscopy in inflammatory and infectious brain disorders. Neuroimaging Clin $\mathrm{N}$
Am 1998;8(4):863-80

21. Chang L, Miller BL, McBride D, et al. Brain lesions in patients with AIDS: H-1 MR spectroscopy. Radiology 1995; 197(2):525-31

22. Chinn RJ, Wilkinson ID, Hall-Craggs MA, et al. Toxoplasmosis and primary central nervous system lymphoma in HIV infection: diagnosis with MR spectroscopy. Radiology 1995;197(3):649-54

23. Chang L, Ernst T. Proton MRS to assess HIV-related brain diseases. In: Weekend Educational Courses: MR spectroscopy Honolulu: International Society for Magnetic Resonance in Medicine; 2002. p.48-55.

24. Shonk TK, Moats RA, Gifford P, et al. Probable Alzheimer disease: diagnosis with proton MR spectroscopy. Radiology 1995;195(1):65-72

25. Castillo M, Kwock L, Mukherji SK. Clinical applications of proton MR spectroscopy. AJNR Am J Neuroradio 1996; 17(1):1-15.

26. Ross BD, Bluml S, Cowan R, et al. In vivo MR spectroscopy of human dementia. Neuroimaging Clin N Am 1998;8(4):809-22.

27. Cwik VA, Hanstock CC, Allen PS, et al. Estimation of brainstem neuronal loss in amyotrophic lateral sclerosis with in vivo proton magnetic resonance spectroscopy. Neurology 1998;50(1):72-7.

28. Bizzi A, Movsas B, Tedeschi G, et al. Response of non-Hodgkin lymphoma to radiation therapy: early and long-term assessmen with H-1 MR spectroscopic imaging. Radiology 1995;194(1):271-6

29. Davidson A, Tait DM, Payne GS, et al. Magnetic resonance spectroscopy in the evaluation of neurotoxicity following cranial irradiation for childhood cancer. Br J Radiol 2000;73(868):421-4.

30. Yoshino E, Ohmori Y, Imahori Y, et al. Irradiation effects on the metabolism of metastatic brain tumors: analysis by positron emission tomography and $1 \mathrm{H}$-magnetic resonance spectroscopy. Stereotact Funct Neurosurg 1996;66(Suppl 1):240-59.

31. Bruhn H, Frahm J, Merboldt KD, et al. Multiple sclerosis in children: cerebral metabolic alterations monitored by localized proton magnetic resonance spectroscopy in vivo. Ann Neurol 1992;32(2):140-50.

32. De Stefano N, Caramanos Z, Preul MC, et al. In vivo differentiation of astrocytic brain tumors and isolated demyelinating lesions of the type seen in multiple sclerosis using $1 \mathrm{H}$ magnetic resonance spectroscopic imaging. Ann Neurol 1998;44(2):273-8

33. Rovira A, Pericot I, Alonso J, Rio J, Grive E, Montalban X. Serial diffusion-weighted MR imaging and proton MR spectroscopy of acute large demyelinating brain lesions: case report. AJNR Am J Neuroradiol 2002;23(6):989-94.

34. Bonavita S, Di Salle F, Tedeschi G. Proton MRS in neurological disorders. Eur J Radiol 1999;30(2):125-31.

35. Ricci PE Jr. Proton MR spectroscopy in ischemic stroke and other vascular disorders. Neuroimaging Clin N Am 1998:8(4):881-900.

36. Malisza KL, Kozlowski P, Peeling J. A review of in vivo $1 \mathrm{H}$ magnetic resonance spectroscopy of cerebral ischemia in rats. Biochem Cell Biol 1998;76(2-3):487-96.

37. Wang Z, Zimmerman RA, Sauter R. Proton MR spectroscopy of the brain: clinically useful information obtained in assessing CNS diseases in children. AJR Am J Roentgeno 1996;167(1):191-9

38. Friedman SD, Brooks WM, Jung RE, et al. Quantitative proton MRS predicts outcome after traumatic brain injury. Neurology 1999;52(7):1384-91

39. Schuhmann MU, Stiller D, Thomas S, Brinker T, Samii M. $1 \mathrm{H}-\mathrm{MR}$ spectroscopic monitoring of posttraumatic metabolism following controlled cortical impact injury: pilot study. Acta
Neurochir Suppl 2000;76:3-7.

40. Sinson G, Bagley LJ, Cecil KM, et al. Magnetization transfe imaging and proton MR spectroscopy in the evaluation of axonal injury: correlation with clinical outcome after traumatic brain injury. AJNR Am J Neuroradiol 2001;22(1):143-51

41. Garnett MR, Blamire AM, Rajagopalan B, Styles P, CadouxHudson TA. Evidence for cellular damage in normal-appearing white matter correlates with injury severity in patients following traumatic brain injury: a magnetic resonance spectroscopy study. Brain 2000;123(Pt 7):1403-9.

42. Gupta RK, Vatsal DK, Husain N, et al. Differentiation of tuberculous from pyogenic brain abscesses with in vivo proton MR spectroscopy and magnetization transfer MR imaging. AJNR Am J Neuroradiol 2001;22(8):1503-9.

43. Kuzniecky R, Hetherington H, Pan J, et al. Proton spectroscopic imaging at 4.1 tesla in patients with malformations of cortical development and epilepsy. Neurology 1997;48(4):1018-24.

44. Cendes F, Caramanos Z, Andermann F, Dubeau F, Arnold DL. Proton magnetic resonance spectroscopic imaging and magnetic resonance imaging volumetry in the lateralization of temporal lobe epilepsy: a series of 100 patients. Ann Neurol 1997;42(5):737-46.

45. Mendes-Ribeiro JA, Soares R, Simōes-Ribeiro F, Guimarães ML Reduction in temporal N-acetylaspartate and creatine (or choline) ratio in temporal lobe epilepsy: does this $1 \mathrm{H}$-magnetic resonance spectroscopy finding mean poor seizure control? J Neurol Neurosurg Psychiatry 1998;65(4):518-22.

46. Kreis R, Ross BD, Farrow NA, Ackerman Z. Metabolic disorders of the brain in chronic hepatic encephalopathy detected with H-1 MR spectroscopy. Radiology 1992;182(1):19-27.

47. Ross BD, Jacobson S, Villamil F, et al. Subclinical hepatic en cephalopathy: proton MR spectroscopic abnormalities. Radiology 1994;193(2):457-63.

48. Sutton LN, Wang Z, Gusnard D, et al. Proton magnetic resonance spectroscopy of pediatric brain tumors. Neurosurgery 1992;31(2):195-202

49. Taylor JS, Ogg RJ, Langston JW. Proton MR spectroscopy of pediatric brain tumors. Neuroimaging Clin N Am 1998;8(4):753-79.

50. Hunter JV, Wang ZJ. MR spectroscopy in pediatric neuroradiology. Magn Reson Imaging Clin N Am 2001;9(1):165-89.

51. Westbrook C, Kaut C. Ressonância magnética prática. Rio de Janeiro: Guanabara Koogan; 2000

52. Barker PB. Fundamentals of clinical MRS. In:. Weekend Educational Courses: MR spectroscopy. Honolulu: International Society for Magnetic Resonance in Medicine; 2002. p.1-9.

53. Negendank WG, Sauter R, Brown TR, et al. Proton magnetic resonance spectroscopy in patients with glial tumors: a multicenter study. J Neurosurg 1996;84(3):449-58.

54. Maudsley AA. Spectroscopic imaging. In: Weekend Educational Courses: MR spectroscopy. Honolulu: International Society for Magnetic Resonance in Medicine; 2002. p.7-23.

55. Dowling C, Bollen AW, Noworolski SM, et al. Preoperative proton MR spectroscopic imaging of brain tumors: correlation with histopathologic analysis of resection specimens. AJNR Am J Neuroradiol 2001;22(4):604-12.

56. Fulham MJ, Bizzi A, Dietz MJ, et al. Mapping of brain tumor metabolites with proton MR spectroscopic imaging: clinical relevance. Radiology 1992;185(3):675-86

57. Moonen CT, von Kienlin M, van Zijl PC, et al. Comparison of single-shot localization methods (STEAM and PRESS) for in vivo proton NMR spectroscopy. NMR Biomed 1989;2(56):201-8.

58. Hwang JH, Egnaczyk GF, Ballard E, et al. Proton MR spectroscopic characteristics of pediatric pilocytic astrocytomas. AJNR Am J Neuroradiol 1998;19(3):535-40.

59. Frahm J, Bruhn H, Hänicke W, et al. Localized proton NMR spectroscopy of brain tumors using short-echo time STEAM 
sequences. J Comput Assist Tomogr 1991;15(6):915-22.

60. Norfray JF, Tomita T, Byrd SE, et al. Clinical impact of MR spectroscopy when MR imaging is indeterminate for pediatric brain tumors. AJR Am J Roentgenol 1999;173(1):119-25

61. Bottomley PA. Spatial localization in NMR spectroscopy in vivo. Ann N Y Acad Sci 1987; 508:333-48.

62. Alger JR. Magnetic resonance spectroscopy and neuro-oncology. In:. Weekend Educational Courses: MR Espectroscopia de prótin. Honolulu: International Society for Magnetic Resonance in Medicine; 2002. p.39-43.

63. Brandāo LA, Domingues RC. Espectroscopia de próton do encéfalo: princípios e aplicaçôes. Rio de Janeiro: Revinter; 2002.

64. Le Bas JF, Estève F, Grand S, et al. Spectroscopie RMN et pathologie cérébrale. Applications cliniques. [NMR spectroscopy and brain diseases. clinical applications]. J Neuroradiol 1998;25(1):55-69.

65. Grand S, Passaro G, Ziegler A, et al. Necrotic tumor versus brain abscess: importance of amino acids detected at $1 \mathrm{H} \mathrm{MR}$ spectroscopy - initial results. Radiology 1999;213(3):785-93.

66. Byrd SE, Tomita T, Palka PS, et al.. Magnetic resonance spectroscopy (MRS) in the evaluation of pediatric brain tumors, Part II: Clinical analysis. J Natl Med Assoc 1996;88(11):717-23.

67. Kinoshita Y, Kajiwara H, Yokota A, Koga Y. Proton magnetic resonance spectroscopy of brain tumors: an in vitro study. Neurosurgery 1994;35(4):606-13; discussion 613-4.

68. Kim DG, Choe WJ, Chang KH, et al. In vivo proton magnetic resonance spectroscopy of central neurocytomas. Neurosurgery 2000;46(2):329-33; discussion 333-4.

69. Norfray JF, Darling C, Byrd S, et al. Short TE proton MRS and neurofibromatosis type 1 intracranial lesions. J Comput Assist Tomogr 1999;23(6):994-1003

70. Auer DP, Gössl C, Schirmer T, Czisch M. Improved analysis of $1 \mathrm{H}-\mathrm{MR}$ spectra in the presence of mobile lipids. Magn Reson
Med 2001;46(3):615-8

71. Hakumäki JM, Kauppinen RA. 1H NMR visible lipids in the life and death of cells. Trends Biochem Sci 2000;25(8):357-62 .

72. Castillo M, Smith JK, Kwock L. Correlation of myo-inositol levels and grading of cerebral astrocytomas. AJNR Am J Neuroradiol 2000;21(9):1645-9.

73. Kimura T, Sako K, Gotoh T, Tanaka K, Tanaka T. In vivo single-voxel proton MR spectroscopy in brain lesions with ringlike enhancement. NMR Biomed 2001;14(6):339-49.

74. Kadota O, Kohno K, Ohue S, Kumon Y, Sakaki S, Kikuchi K, et al. Discrimination of brain abscess and cystic tumor by in vivo proton magnetic resonance spectroscopy. Neurol Med Chir 2001;41(3):121-6.

75. Schlemmer HP, Bachert P, Herfarth KK, Zuna I, Debus J, van Kaick G. Proton MR spectroscopic evaluation of suspicious brain lesions after stereotactic radiotherapy. AJNR Am J Neuroradio 2001;22(7):1316-24
. PUBLISHING INFORMATION

Acknowledgments: The authors are grateful to llydio Polachini Júnior (in memoriam) for his support in the development of proton magnetic resonance spectroscopy in São José do Rio Preto, São Paulo State, Brazil, and to Carlos Daghlian (Universidade Estadual Paulista - São José do Rio Preto) for reviewing the English text.

Sérgio Luiz Ramin, MD. Discipline of Neurosurgery, Department of Neurological Sciences, Faculdade de Medicina de São José do Rio Preto, São José do Rio Preto, São Paulo, Brazil.

Waldir Antônio Tognola, MD, PhD. Head of the Discipline of Neurology, Department of Neurological Sciences, Faculdade de Medicina de São José do Rio Preto, São José do Rio Preto, São Paulo, Brazil.

Antonio Ronaldo Spotti, MD, PhD. Discipline of Neurosurgery, Department of Neurological Sciences, Faculdade de Medicina de São José do Rio Preto, São José do Rio Preto, São Paulo, Brazil.

Sources of funding: Not declared

Conflict of Interest: None

Date of first submission: November 21, 2002

Last received: March 7, 2003

Accepted: May 30, 2003

Address for correspondence: Sérgio Luiz Ramin

Av. José Munia, 4850

São José do Rio Preto/SP

Brasil - CEP 15090-500

Tel. (+ 55 17) 3216-9999

E-mail: sergioramin@cerebroecoluna.com.br
Espectroscopia de prótons por ressonância mag nética: aplicaçôes clínicas em pacientes com lesōes encefálicas

CONTEXTO: A espectroscopia de prótons é reconhecidamente um método não invasivo que, quando associada à imagem por ressonância magnética, possibilita a correlação de alteraçôes metabólicas e bioquímicas com mudanças fisiológicas e anatômicas dentro de um volume previamente determinado no encéfalo. Existem dois métodos de espectroscopia de prótons por ressonância magnética: volume único de interesse (single voxel) e imagem espectroscópica (chemical shift imaging).

OBJETIVO: Este trabalho discute as aplicações clínicas da espectroscopia de prótons por res-
RESUMO

sonância magnética em pacientes com lesões encefálicas.

CONCLUSÔES: A espectroscopia de próton por ressonância magnética in vivo permite detectar alguns metabólitos existentes no tecido encefálico, como $\mathrm{N}$-acetil aspartato, creatina, colina, mio-inositol, aminoácidos, lipídios, entre outros. $\mathrm{O} \mathrm{N}$-acetil aspartato é um marcador neuronal cuja concentração diminui quando há lesão encefálica. $\mathrm{O}$ aumento na concentração de colina é o principal indicador de doenças neoplásicas. A quantidade de mio-inositol apresenta-se aumentada em casos de doença de Alzheimer. Aminoácidos estão presentes em abscessos encefálicos. A presença de lipídios está relacionada à necrose tecidual.

PALAVRAS-CHAVE: Espectroscopia de prótons. Ressonância magnética. Encéfalo. 